\title{
Private-label sustainable supplier selection using a fuzzy entropy-VIKOR-based approach
}

\author{
Jun Zhang ${ }^{1}$ - Linze $\mathrm{Li}^{1} \cdot$ Jing Zhang ${ }^{1} \cdot$ Liping Chen $^{2} \cdot$ Guojiao Chen ${ }^{1}$
}

Received: 13 November 2020 / Accepted: 1 March 2021

(c) The Author(s) 2021

\begin{abstract}
In recent decades, private labels have been the focus of great development in retail due to their price advantage and consumeroriented production. With growing customer awareness of safety and health, private-label sustainable supplier selection has become a strategic issue for many retailers. Although there are many studies on supplier selection issues and evaluation methods, studies on the sustainability and consumption sectors are rather limited. Therefore, a novel three-phase MCDM model for private-label supplier selection compliance with sustainability criteria is proposed. First, the Delphi method is used to construct a criteria system based on a detailed literature review. Then, an integrated weight algorithm is suggested, in which objective weights are based on attributes' entropy measurements, and subjective weights are derived from decision-makers' preferences. Eventually, during evaluation, a fuzzy set extended in VIKOR is exploited by considering the vagueness of decision makers' expressions. The results from a case study then show that green packaging and labelling, relationship with manufacturing brand, order flexibility, and product traceability are the most important criteria in retail private-label supplier selection. The flexibility and reliability of the proposed model are also demonstrated in a practical case of supplier evaluation.
\end{abstract}

Keywords Supplier selection $\cdot$ Entropy $\cdot$ VIKOR $\cdot$ Sustainability $\cdot$ Private labels

\section{Introduction}

In modern times, the idea of improving organizational performance has changed significantly. Sustainability is becoming increasingly important for organizations with an emphasis on sustainable development through strict government guidance and growing green knowledge of customers [5, $34,57]$. Retailers acting as middlemen between manufacturers and consumers should be more concerned about ethical values while still creating economic values. Therefore, introducing sustainability as a core value is one of the most promising meanings to achieve maximum ecological-economic benefits [32, 54]. In view of the current retail market, a growing number of retailers are attempting to place their private labels (i.e., retailer brands or store brands) at the center of their strategies [20]. Retail private labels are owned

Linze $\mathrm{Li}$

lilinze@cueb.edu.cn

1 Management Engineering School, Capital University of Economics and Business, Beijing, China

2 College of Business Administration, Capital University of Economics and Business, Beijing, China and/or licensed exclusively by retailers for distribution in their respective segments of the marketplace [24]. Retailers attempt to use exclusive brands to differentiate products from their competitors [29]. In North America and Europe, private-label product sales also increase dramatically to $22 \%$ and $30 \%$ market shares of consumer-packaged goods, respectively $[37,40]$. Private-label goods are normally priced $20 \%$ or more below manufacturer brand market leaders. In large Western chain supermarkets, the objective quality gap between retailer brands and leading national brands is small-to-none. Lower prices and higher qualities of products are more in line with corporate and social sustainability.

Any strategy that relies on privately branded merchandise must also address a host of complex problems on the supply-chain side. Most private-label supply-chain research has concentrated on this topic, primarily including customers' behaviors [38] and marketing strategies [17]. However, the major challenges that retail private labels face focus on the upstream supply chain in product manufacturing, which begins with qualifying factories that create products. Privatelabel manufacturers differ from general manufacturers in that they have specific categories and characteristics. The Private Label Manufacturer's Association (PLMA) divides suppliers 
into four categories, as shown in Table 1 [41]; however, this process requires a specific criteria system to evaluate private-label suppliers' performance. Existing research has used supplier selection mechanisms in economic, green, and social concerns [3, 5, 28], and existing supplier selection criteria systems are primarily in the manufacturing industry. For example, in the textile industry, social-focused criteria, such as long working hours and employment of child labor, are critical [8]. In the motor industry, environmental factors have become the most critical criteria [28]. However, compared to manufacturing, more criteria should be published in the consumption sector.

This paper stresses private-label sustainability practices as criteria for supplier selection and evaluation in three dimensions: economic, environmental, and social. In this context, we propose a three-phase MCDM approach as the private-label sustainable supplier selection (PL-SSS) model. We investigate more than 60 supermarket chains and interview many relevant experts to establish PL-SSS criteria. Also, we markedly improve the effectiveness and efficiency of weight measurement by integrating both subjective and objective weights. Finally, the proposed PL-SSS is applied to a real and typical business case study of a Chinese grocery chain. The Chinese grocery industry is fragmented, and mainly consists of small- and medium-sized enterprises (SMEs), which are regional retailers that play important roles in the Chinese national economy and daily life. Although Chinese grocery chains and supermarket chains have been developing for many years, private labels in China are relatively new. Private-label categories and products are rare and typically focus on food items. A large proportion of regional retailers have no private-label products. To become more competitive, Chinese regional retailers must use supply-chain management practices to secure privatelabel product supply and minimize quality gaps with leading manufacturing brands. Compared to international supermarket chains, such as Walmart and Tesco, which have manufacturing expertise and factories, research of PL-SSS issues among Chinese regional retailers is more impactful [11].

The remainder of this paper is organized as follows. "Literature review" reviews relevant literature, and the proposed model and methods are described in "Methods".
"Results and discussion" then compares the results and provides a discussion based on a case study. Finally, "Conclusions" provides concluding observations, limitations, and suggestions for future work.

\section{Literature review}

The increase in research on supplier selection criteria and performance evaluation since the 1960s was encouraged by both academia and business. Dickson [21] is one of the first representatives in this research field and identified 23 criteria based on questionnaire research from organization managers in North America. In the subsequent decades, a significant impetus of just-in-time manufacturing strategies changed the procurement strategy, and implementation imposed a reordering of the vendor selection criteria. At that time, the preponderant criteria of vendor selection concentrated on economic factors, including quality, delivery, net price, production facilities, and capacity [10, $13,35,36]$.

Typically, a new strategic direction requires new criteria and/or the re-emphasis on existing criteria used in purchasing decisions necessary to use them [53]. Given the recent focus on sustainability issues, the main purpose of this section is to review documents about supplier selection issues published in the last decade and provide a systematic review of criteria (Table 2) related to sustainability practice. We use the triple bottom line (TBL) model to define sustainability in terms of economic, environmental, and social aspects, which is then described by various criteria [23].

This review will help define sustainability issues and focuses on private-label supplier selection in "Sustainability and supplier selection". We also review the literature over the last decade in "Sustainability and supplier selection" to identify important sustainable supplier selection criteria and effective supplier evaluation methods. Based on this review, "Research gaps" shows current research gaps and the contributions of this study.

Table 1 Private-label manufacturer's category

\begin{tabular}{ll}
\hline Private-label manufacturer's category & Features \\
\hline Large national brand manufacturers (LNBMs) & Utilize their expertise and excess plant capacity to supply private labels \\
Small and quality manufacturers (SQMs) & Specialize in given product lines \\
& Nearly focus on private-label production \\
& Companies often own by LNBMs \\
Major retailers and wholesalers (MRWs) & Have self-developed capacity and own manufacturing facilities \\
Regional brand manufacturers (RBWs) & Produce store-brand products for specific markets
\end{tabular}




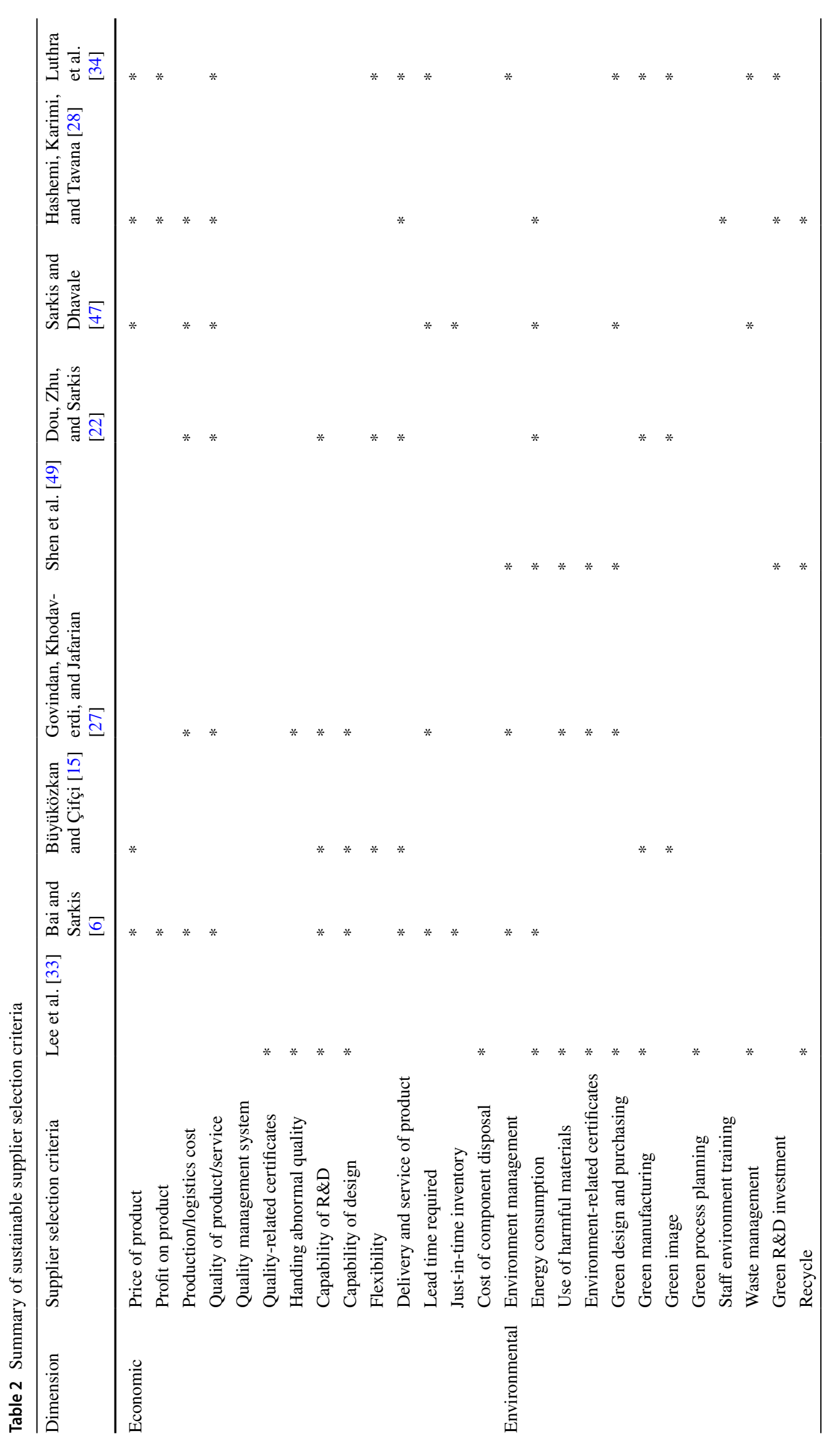




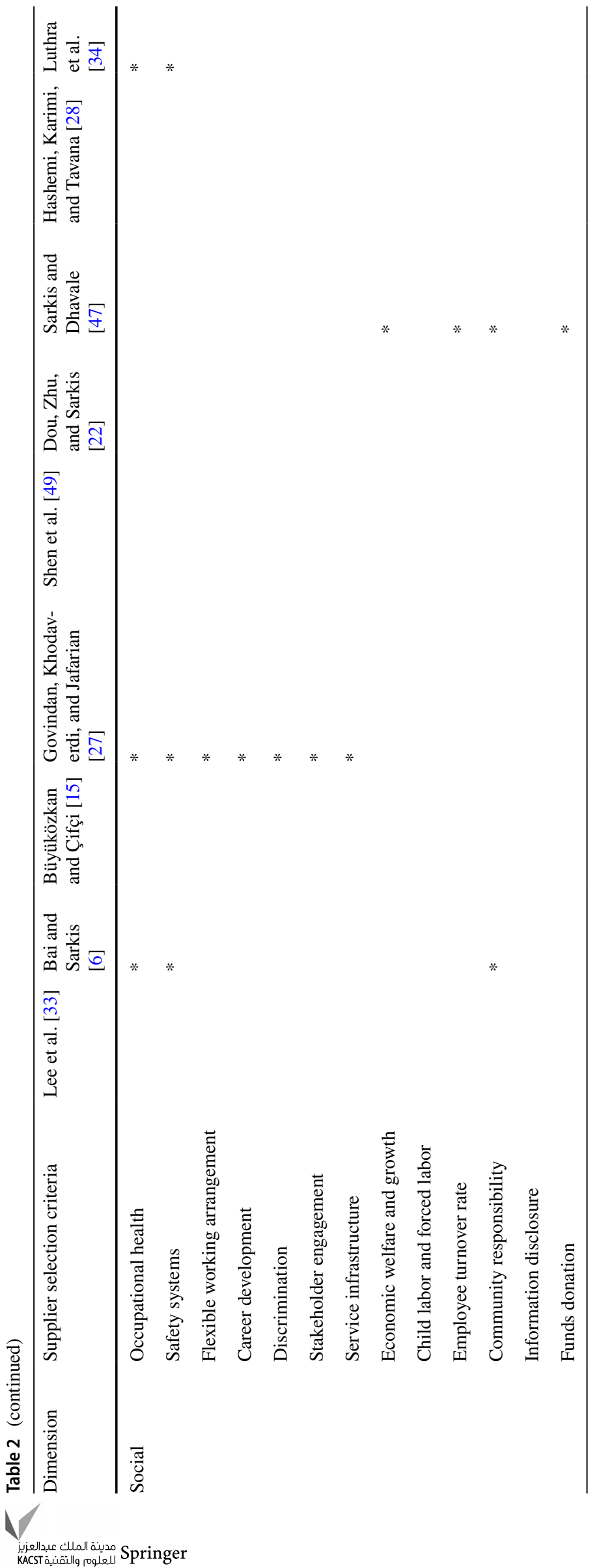




\section{Sustainability and supplier selection}

Many researchers and organizations attempt to define sustainability in various ways. The most originally and frequently cited definition is from the United Nations World Commission on Environment and Development, which states that "sustainable development is development that meets the needs of the present without compromising the ability of future generations to meet their own" [16]. However, this definition lacks a practical understanding of sustainability, particularly its application in specific situations. An important developing trend links sustainability to the TBL model, as described by Elkington [23], to incorporate economic, environmental, and social dimensions of sustainability into the supply chain and management practices [44].

In response to growing market pressures and stakeholders' demands and compliance with strict sustainable development regulations, organizations review their supply chain, and firms have described the importance of their suppliers' sustainable performance in sustainable supply-chain management [6]. Supplier selection and evaluation thus become some of the most significant strategic decisions that corporations make [14]. The requirement of organizations' sustainable development for supplier selection and evaluation is to identify the most appropriate suppliers that consistently satisfy the firms' sustainable demands at acceptable cost.

With private brand joining, the retail supply chain is shortened forward (Fig. 1); therefore, retailers are move closer to their suppliers. A new issue of PL-SSS arises in retail supply-chain management between manufacturers and retailers. According to Zimmer et al. [58], and Akman and Pışkın [2], PL-SSS is a process by which retailers evaluate suppliers and select the best supplier regarding sustainability to achieve competitiveness on products against national brands. The steps for the supplier selection process typically

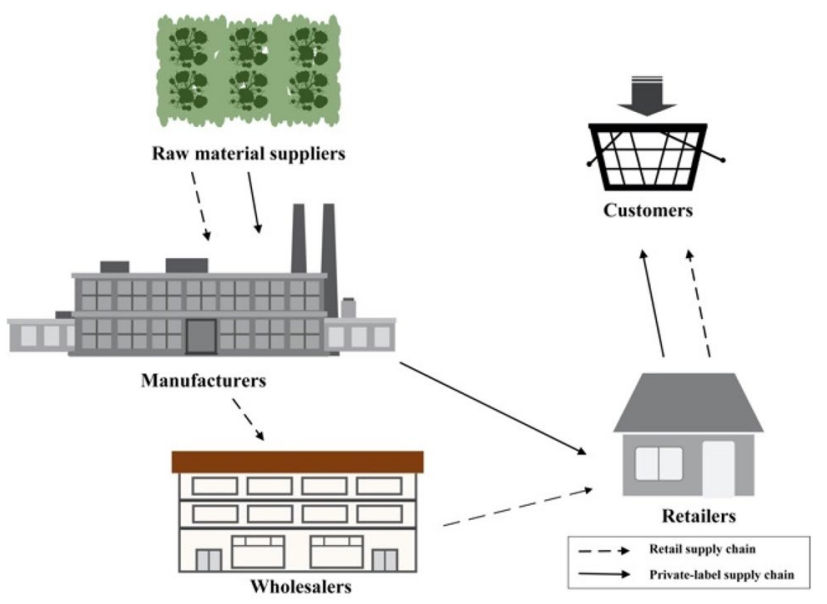

Fig. 1 Retail and private-label supply-chain begin with identifying overall objectives and specifications, continuing with criteria formulation [19, 31]. Then, through the first rough screening step with candidate submission, the final detailed evaluation procedures are enforced among qualified manufacturers. However, two types of problems tend to occur in sustainable supplier selection and evaluation processes arising from researchers: the lack of sustainable evaluation criteria [1] and the diversity of suppliers and criteria [6].

\section{Sustainability and supplier selection}

We review the most cited articles in the last decade that are associated with relevant keywords to construct a co-citation analysis network (see Fig. 2), and the 14 articles with the highest co-citations are then described. Based on the results of this review, we conducted a systemic analysis with these 14 articles. Supplier selection is a typical decision-making activity. Given the multiplicity and complexity of this process, we summarize the collected literature in Table 2, focusing on supplier selection criteria, and Table 3 in three aspects: (1) issues addressed, (2) industries involved, and (3) methodologies used.

\section{Research gaps}

In supply-chain activities, building appropriate sustainability-focused criteria is important for organizations to achieve sustainable development. Several studies have incorporated green criteria $[15,22,28,33,42,49]$ and sustainable criteria $[6,14,34,47]$ during supplier selection. However, a few contribute to specific industries. Most research only applies a numerical example to verify the proposed supplier

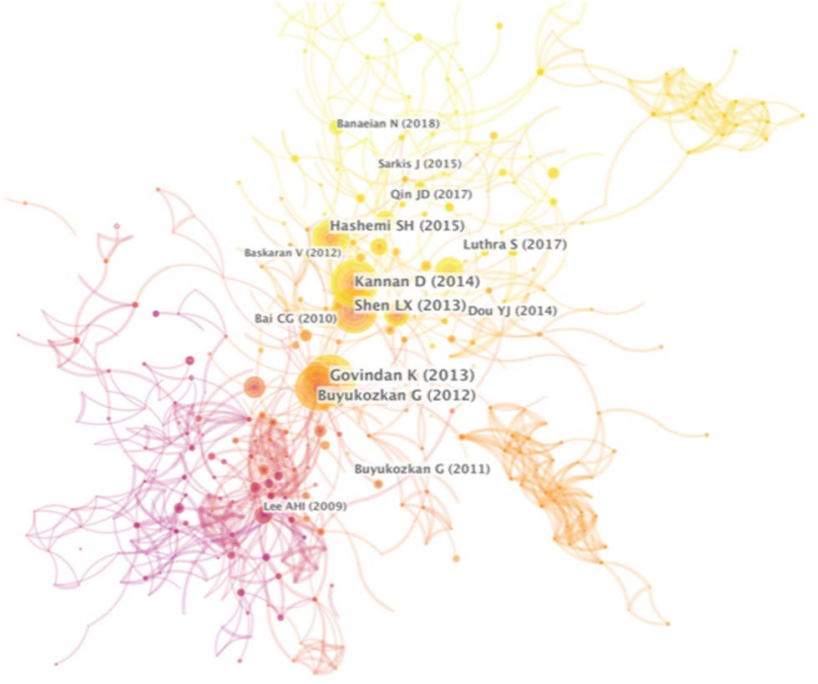

Fig. 2 Co-citation analysis network

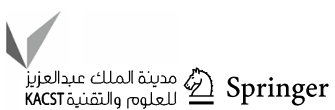




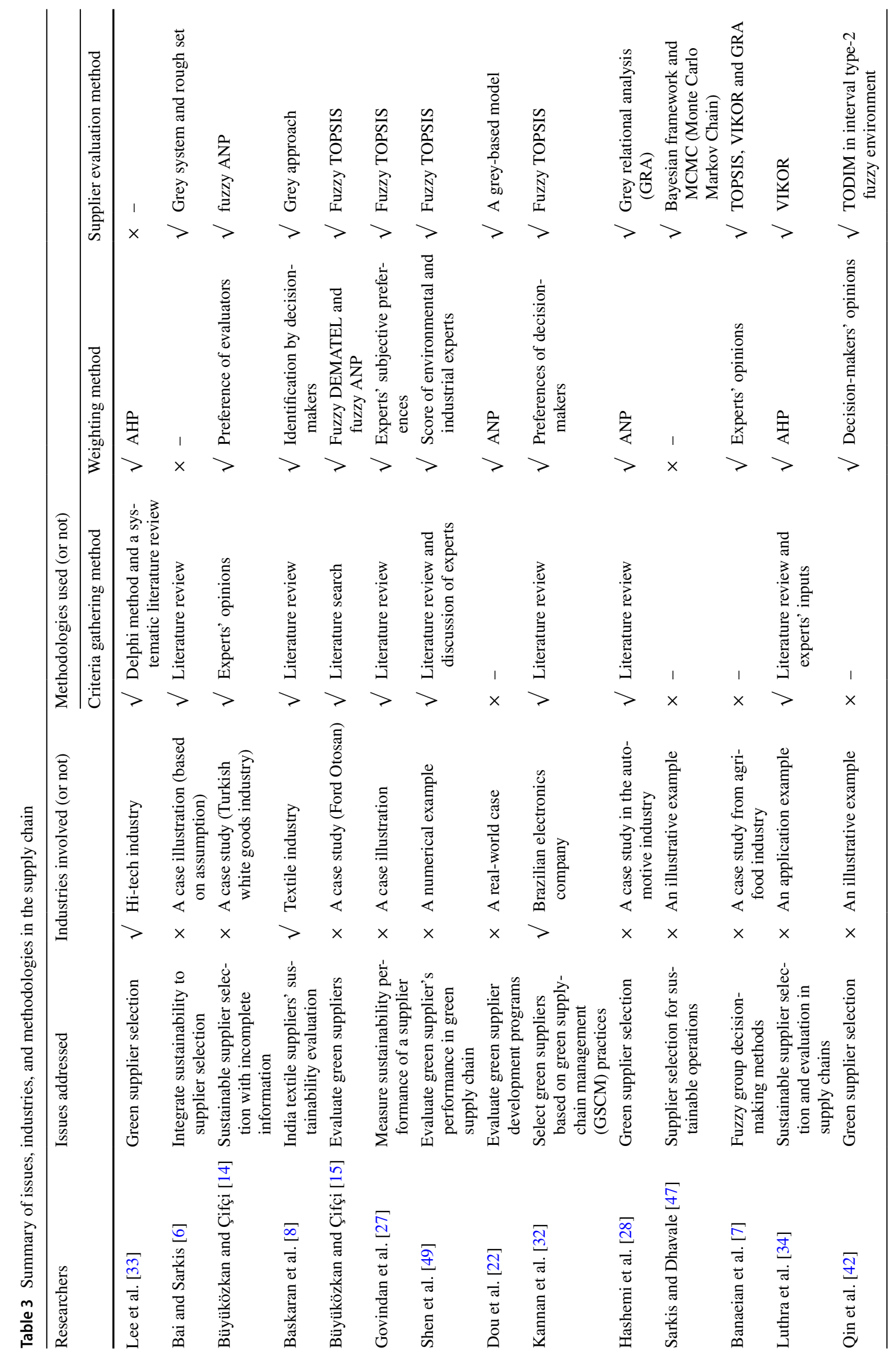


selection model [27, 34, 42, 47, 49]. Although certain studies focus on a particular industry, such as the hi-tech industry [33], textile industry [8], electronic industry [32], and steel industry [4], these studies primarily concentrate on upstream supply chains rather than downstream industries; thus, a significant lack of research has been conducted on the establishment of supplier selection criteria in retail industries.

Existing criteria systems are primarily based on literature reviews and a lack of empirical research that is likely due to limited research scopes or targets [27, 34, 42, 47, 49]. These facts may cause difficulty when applying these criteria to practical business decision-making tasks. Also, index weighting is primarily based on subjective assessments, such as AHP [33, 34], ANP [22, 28], preferences of decisionmakers [14, 32, 42], and experts' opinions [7, 27, 47]. There thus remain subjective interference characteristics in these traditional weight methods.

To fill these gaps in research, we propose the PL-SSS model, which is an initial effort concentrated on the consumption sector. We first attempt to establish PL-SSS criteria system. Both theoretical and empirical models are used in criteria establishment, and the TBL method and a systematic literature review are used to build a rough criteria system (Table 2). The modified Delphi method is used to complete the criteria system, which helps focus and quantify the valuation of criteria. Then, a significant effort we made is to suggest a dynamic constitution evaluation that integrates subjective and objective weight assessments. To mitigate subjective bias, we use the entropy method to measure the objective weights of criteria, which is related to supplier performance rather than the judgement of decision-makers. Also, we use the fuzzy VIKOR method to evaluate suppliers and compare its results with TOPSIS. To the best our knowledge, this research is an original attempt to propose a research framework for establishing a PL-SSS model and criteria system.

\section{Methods}

As mentioned above, applying the fuzzy entropy-VIKOR approach to solve the PL-SSS problem is viewed as a threephase MCDM model, including criteria system establishment, weight computing, and supplier evaluation. In this study, the PL-SSS model is introduced (Fig. 3) and relates to mathematical preliminaries that can be divided into five parts: the Delphi method, fuzzy set theory, data pre-processing, entropy method, and VIKOR. The Delphi method is used to screen the criteria and establish an indicator system in "Delphi method". Then, "Linguistic variable and data preprocessing" introduces a triangular fuzzy number (TFN) to express decision-makers' judgements, in which we propose a data processing algorithm to manage linguistic variables.
The entropy method is used to obtain objective criteria, and the specific comprehensive weight measurement is described in "Weight measurement method". We use VIKOR as the evaluation approach in "Fuzzy VIKOR".

\section{Delphi method}

The Delphi method is a structural communication method that was initially developed for business forecasting based on the results of multiple rounds of interviews and/or questionnaires from a panel of experts $[12,18,46]$. In its application, the Delphi method has been developed from general forecasting to broad research subjects, such as reporting guidelines [52] and public policy-making [25].

In this study, the Delphi method is embedded in supplier selection research to develop its criteria system. According to Saaty [45], if there are more than seven attributes at the same level, it is difficult for decision-makers to assess due to redundant standards; this problem could be resolved by combining or eliminating some criteria. Based on a literature review (Table 2), the Delphi method is used to reduce the number of irrelevant criteria and maintain effective evaluation attributes, and is performed as described in Fig. 4.

\section{Linguistic variable and data pre-processing}

In certain situations, crisp numbers cannot accurately model the judgement of decision-makers due to their vagueness and uncertainty. In such cases, fuzzy set theory is typically used to model decision-makers' opinions. Zadeh [56] introduced fuzzy set theory as an extension of classic set theory to manage imprecise information and expression by mapping linguistic terms to numerical variables. Also, Bellman and Zadeh [9] applied this theory to create fuzzy multiplecriteria decision-making (FMCDM) technology, which calculates weight assignments and alternative ranks compared to proposed criteria. The character of a fuzzy set is a membership function, which permits the gradual assessment of each element's membership within the interval $[0,1]$. Thus, defined numerical intervals could be used to describe general linguistics terms, such as "good", "fair", or "bad", in fuzzy logic. The definitions and notations of fuzzy set theory used in this study are shown (Tables 4, 5, 6) (Figs. 5, 6).

The preliminary work of supplier evaluation defines a criteria evaluation matrix and a decision matrix. To simplify and eliminate repetitive computation, we conduct data preprocessing to obtain a crisp subjective matrix and decision matrix before the evaluation stage begins. Based on the foregoing fuzzy set, we assume that $\tilde{W}_{k}^{s}$ is a fuzzy criteria evaluation matrix, in which $\tilde{w}_{j k}^{s}$ represents $k$ th decision-makers $(k=1,2, \ldots, K)$ which evaluate $c_{j}$ criteria $(j=1,2, \ldots, n)$; $\tilde{D}_{k}$ is a fuzzy decision matrix; and $\tilde{r}_{i j k}^{s}$ indicates that the $k$ th 


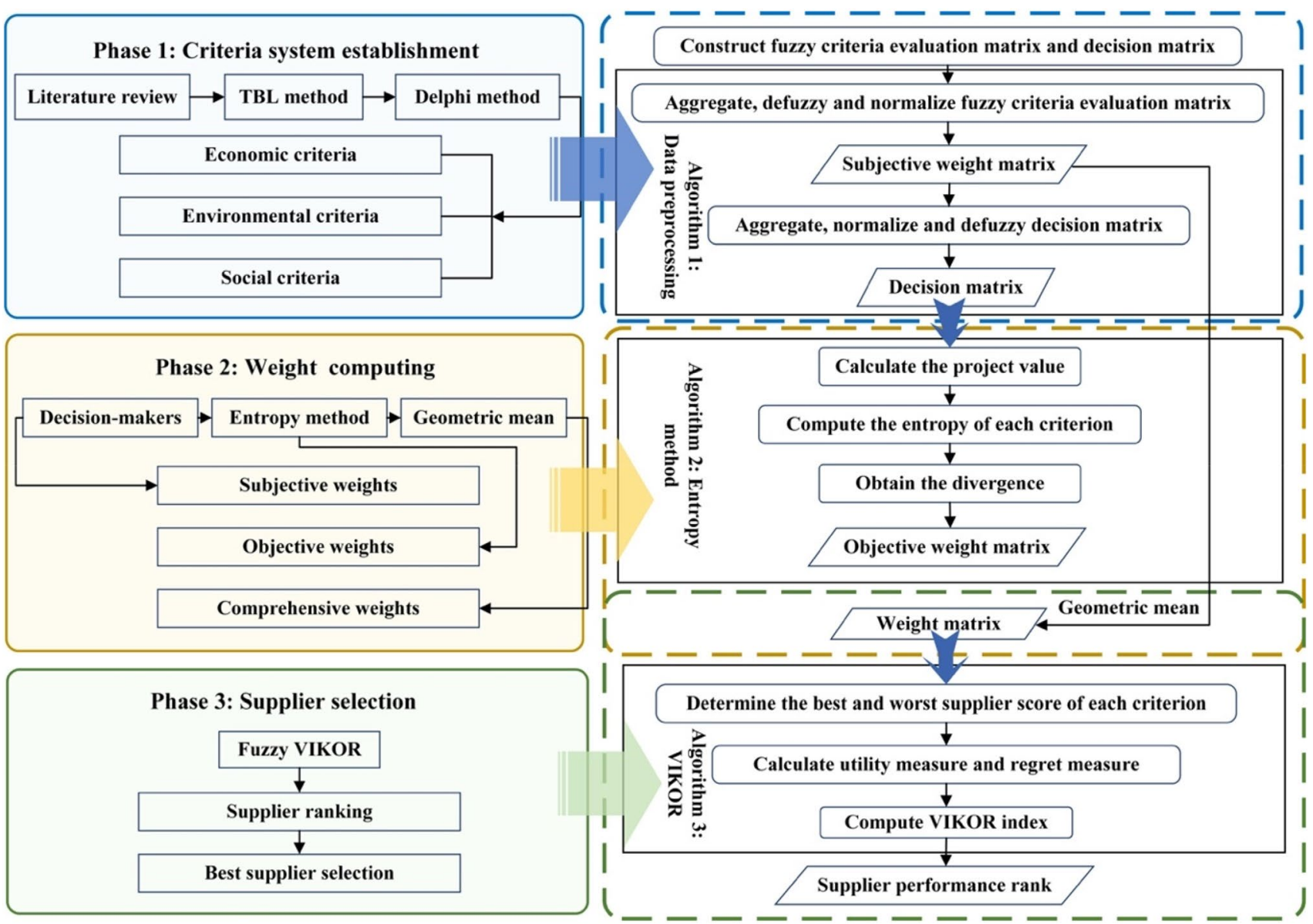

Fig. 3 PL-SSS model framework

Fig. 4 Three-round Delphi method
Delphi Method-Stage for PL-SSS Criteria System Development

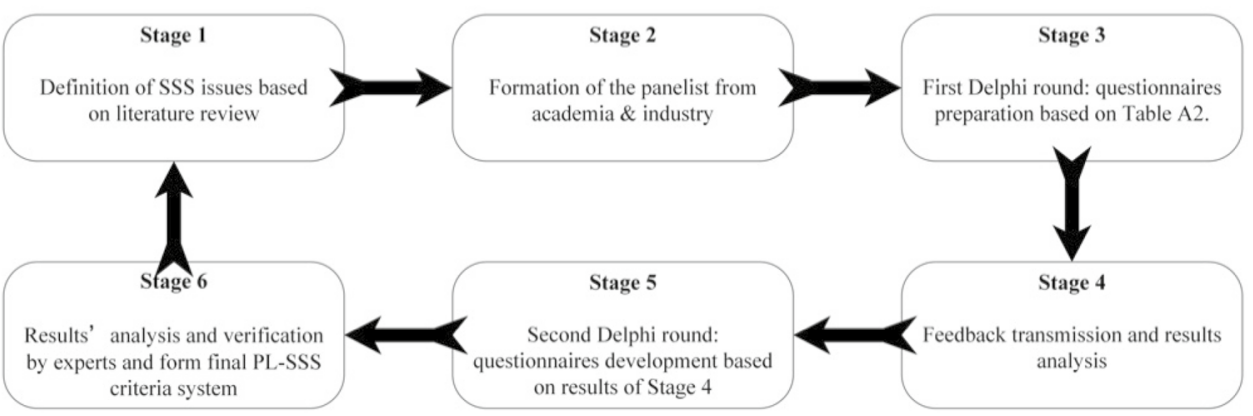

decision-maker evaluates the $A_{i}$ alternative based on $c_{j}$. The specific data process is shown in Table 7.

\section{Weight measurement method}

In the weighting process, there are two different weight measurements: subjective and objective. Subjective weight measurement is a conventional method is solely determined by decision-makers or experts, and objective weight measurement is typically based on mathematical approaches, such as multiple objective programming and entropy methods. To establish a more reasonable and effective weight system, we integrate subjective and objective weights into a comprehensive weight system, in which the entropy method is introduced to determine objective weights.

Initially proposed by Shannon [48], entropy is a measurable physical property that represents the unavailability of a system's thermal energy for conversion into mechanical 
Table 4 Notion and operational rules in fuzzy theory utilization

Fuzzy set notion and operational rules

Fuzzy set: A fuzzy set is a pair $(X, m)$, where $X$ is the universe of discourse and $m: X \rightarrow[0,1]$ is a membership function. Let $A$ be a fuzzy set, and the function $m=\mu_{A}$. For a finite set $X=\left\{x_{1}, x_{2}, \ldots, x_{m}\right\}, A=\left\{\left(x_{1}, \mu_{A}\left(x_{1}\right)\right),\left(x_{2}, \mu_{A}\left(x_{2}\right)\right), \ldots,\left(x_{m}, \mu_{A}\left(x_{m}\right)\right)\right\}$

Triangular fuzzy number: A triangular fuzzy number (TFN) is denoted as a triplet $A\{(a, b, c) \mid a, b, c \in R ; a \leq b \leq c\}$, which respectively describes the smallest probable value, the most promising value, and the largest possible value to depict a fuzzy term. The membership function of a TFN $\mu_{A}(x)$ is defined and shown as follows:

$\mu_{A}(x)= \begin{cases}0, & x \leq a \\ \frac{x-a}{b-a}, & a<x \leq b \\ c-x & b<x \leq c \\ c-b & b>c\end{cases}$

Aggregate rules: Assuming a set $\tilde{r}_{k}=\left\{\left(a_{k}, b_{k}, c_{k}\right) \mid k=1,2, \ldots, K\right\}$, the aggregate triangular fuzzy number $\tilde{r}=(a, b, c)$ is defined as:

$\tilde{r}=\left\{\begin{array}{l}a=\min _{k}\left\{a_{k}\right\} \\ b=\frac{1}{K} \sum_{k=1}^{K} b_{k} . \\ c=\max _{k}\left\{c_{k}\right\}\end{array}\right.$

Defuzzy rules: Assuming a triangular fuzzy number $\tilde{r}=(a, b, c)$, defuzzification is computing as:

$\bar{r}=\frac{a+2 b+c}{4}$

Linguistic variable: There are two set of proper linguistic variables: one for criteria evaluation (Table 5, Fig. 5), and another for supplier estimate (Table 6, Fig. 6).

Table 5 Linguistic variables for weighting criteria

\begin{tabular}{ll}
\hline Linguistic expression & Fuzzy numbers \\
\hline Very low (VL) & $(0,0.2,0.4)$ \\
Low (L) & $(0.2,0.4,0.5)$ \\
Medium (M) & $(0.4,0.6,0.8)$ \\
Hight (H) & $(0.6,0.8,1)$ \\
Very high (VH) & $(0.8,0.9,1)$ \\
\hline
\end{tabular}

Table 6 Linguistic variables for rate suppliers

\begin{tabular}{ll}
\hline Linguistic expression & Fuzzy numbers \\
\hline Very poor (VP) & $(0,0,1)$ \\
Poor (P) & $(0,1,3)$ \\
Medium poor (MP) & $(1,3,5)$ \\
Fair (F) & $(3,5,7)$ \\
Medium good (MG) & $(5,7,9)$ \\
Good (G) & $(7,9,10)$ \\
Very good (VG) & $(9,10,10)$ \\
\hline
\end{tabular}

work that is most commonly associated with a state of randomness, disorder, or uncertainty. Entropy has been widely used in various fields, including spectral analysis [50], language modeling [43], and economics [26]. In this study, entropy is interpreted as dispersion, which is used to weight calculation, because it measures the relative contrast intensities of attributes to present average intrinsic information. According to Wang and Lee [51], the entropy

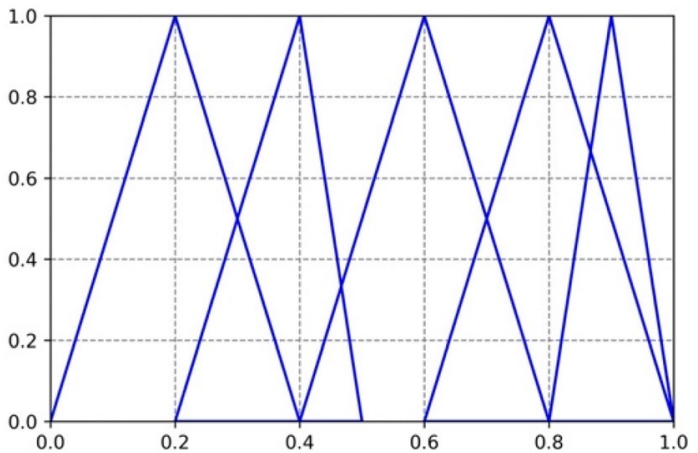

Fig. 5 TFNs for criteria

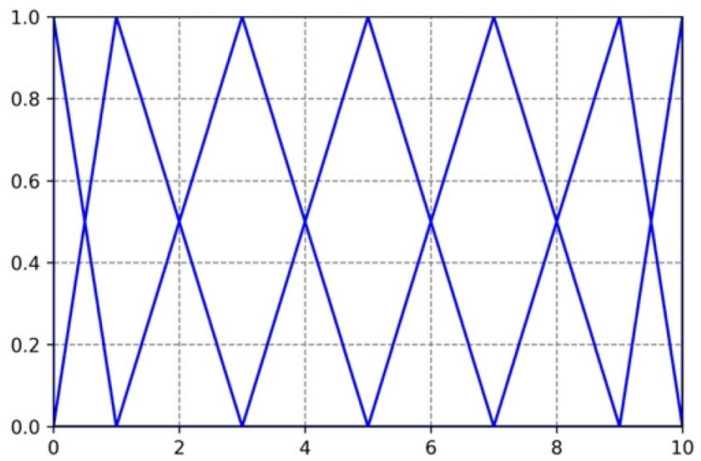

Fig. 6 TFNs for alternatives

method is used as an objective weight computing method. We propose a comprehensive weight model by merging the entropy method and decision-makers' judgements, and the specific algorithm is shown in Table 8 . 
Table 7 Data pre-processing

Table 8 Comprehensive weight measurement based on subjective and objective methods

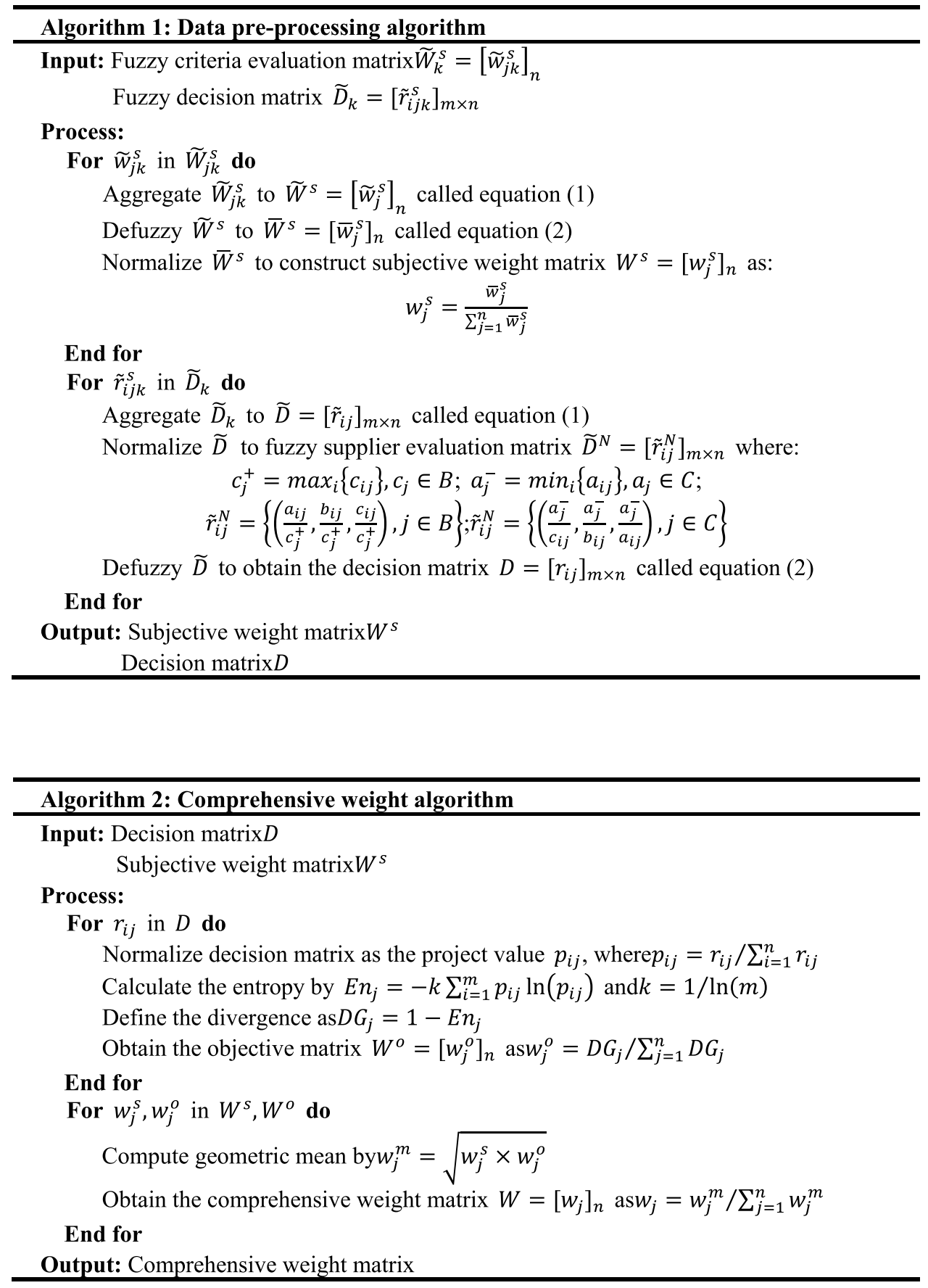

\section{Fuzzy VIKOR}

Disagreements among decision-makers typically come from differences in subjective evaluations of alternatives. The VIKOR method is used to resolve potential divisions of opinions. Yu [55] introduced the idea of a compromise solution to minimize the group regret based on maximum group utility $\left(S_{i}\right)$ and the minimum solution $\left(R_{i}\right)$. Opricovic [39] extended the theory to extend the VIKOR
(Vlsekriterijumska Optimizacija I Kompromisno Resenje) method into multiple-criteria optimization, in which the notion of compromise programming was introduced to rank alternatives against probable conflicts. The specific VIKOR algorithm is shown in Table 9.

The alternative $A^{(1)}$ is a compromise solution that is ranked best in the $Q$ minimum measurement when the following two conditions are satisfied: 
Table 9 VIKOR method in the PL-SSS method

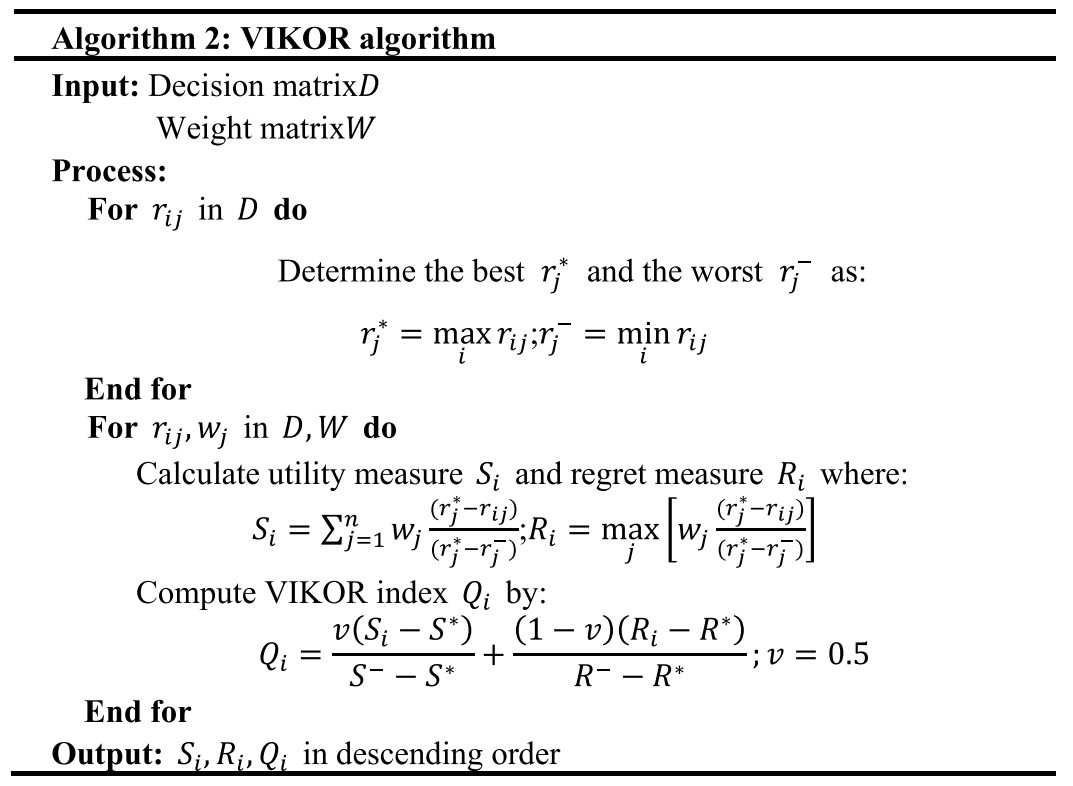

1. Acceptable advantage: $Q\left(A^{(2)}\right)-Q\left(A^{(1)}\right) \geq D Q$, where $A^{(2)}$ is the 2 nd minimum in the $Q$ rank; $D Q=1 / m-1$; and $m$ is the number of alternatives;

2. Acceptable stability: $A^{(1)}$ is stable and ranked best by $S$ and/or $R$.

If one of the conditions cannot be satisfied, a set of compromise solutions is proposed, which include:

1. $A^{(1)}$ and $A^{(2)}$, if only condition (2) is not satisfied;

2. $A^{(1)}, A^{(2)}, \ldots, A^{(k)}$, if condition (1) is not satisfied. $A^{(k)}$ is determined by the relation $Q\left(A^{(k)}\right)-Q\left(A^{(1)}\right)<D Q$ for maximum $k$ (positions of alternative solutions are "in closeness").

\section{Results and discussion}

We conducted an empirical study of a retail alliance that consisted of 68 regional retailers operating more than 2000 stores spread over 29 provinces in China. The members of the alliance serve $20 \%$ of Chinese customers, and their overall sales are approximately 80 billion RMB ( 1 USD $\cong 7.1$ RMB). Member enterprises are devoted to developing their own-brand products and tend to achieve marked advantages over rivals via customized and differentiated products.

Some of the major challenges that members encountered include a lack of production flexibility, low design capacity, and a lack of availability of guidelines for private-label development. Regional retailers depend on manufacturers to produce more total SKUs with lower volumes and to provide frequent changes to products to avoid obsolescence. This process makes it difficult to ensure that vendor production meets strict quality standards while meeting retailer's ethical guidelines. To manage this complexity and provide highquality products, retailers require expertise and evaluation criteria in supplier selection.

One of the alliance members, a regional retailer in Hefei city that operates more than 200 fresh food groceries, has used the proposed model as its decision-making technique to evaluate suppliers. We construct the evaluation criteria in "PL-SSS Criteria system establishment" and conduct the procedures of the weight and evaluation algorithm in "Weight computing" and "Supplier evaluation", respectively.

\section{PL-SSS criteria system establishment}

In the first phase, the Delphi method is used to generate consensus on the panel's opinions and extract the most appropriate PL-SSS criteria based on the literature research (Table 2). We invited eight experienced practitioners from the alliance to be industry experts. To select panelists, each expert had to stand for one specific perspective with regard to the research topic, considering that individual opinions may impact the study's results. Following this principle, the selected practitioners were from different departments. Also, six academics, including retail and sustainability professors, were included as panelists. Table 10 shows the demographics of the panelists.

A five-point scale was used in the Delphi questionnaire to gather panelists' feedback regarding their preferences about various topics, which were very important, important, ambivalent, unimportant, and very unimportant. We also appended several empty rows for experts to add new and 
Table 10 Delphi panelists' information

\begin{tabular}{|c|c|c|c|c|}
\hline Expert (no.) & Academic/practitioner & Job title/Area of expertise & Sector & Job experience \\
\hline Expert 1 & Academic & Professor for retail & Higher education & 20 years \\
\hline Expert 2 & Academic & Professor for supply chain & Higher education & 13 years \\
\hline Expert 3 & Academic & Dean of information technology & Higher education & 17 years \\
\hline Expert 4 & Academic & Professor for retail & Higher education & 15 years \\
\hline Expert 5 & Academic & Professor for corporate ethics & Higher education & 7 years \\
\hline Expert 6 & Academic & Professor for private labels & Higher education & 6 years \\
\hline Expert 7 & Practitioner & Chamber of retail alliance & Retail alliance & 3 years \\
\hline Expert 8 & Practitioner & Head of private-label department & Retail alliance & 2 years \\
\hline Expert 9 & Practitioner & Own-brand purchasing manager & Retail alliance & 2 years \\
\hline Expert 10 & Practitioner & Purchasing advisor & Consulting & 14 years \\
\hline Expert 11 & Practitioner & Procurement director & Chain supermarket & 10 years \\
\hline Expert 12 & Practitioner & Senior manager & Chain supermarket & 11 years \\
\hline Expert 13 & Practitioner & Shop manager & Chain supermarket & 7 years \\
\hline Expert 14 & Practitioner & Marketing manager & Chain supermarket & 10 years \\
\hline
\end{tabular}

Table 11 Excerpt of the Delphi questionnaire

\begin{tabular}{|c|c|c|c|c|c|}
\hline \multicolumn{6}{|l|}{ Delphi questionnaire } \\
\hline \multirow[t]{3}{*}{ Criteria/sub-criteria } & \multicolumn{5}{|c|}{ Importance of sub-criteria for private-label suppliers } \\
\hline & Very important & Important & Ambivalent & Unimportant & $\begin{array}{l}\text { Very } \\
\text { unim- } \\
\text { portant }\end{array}$ \\
\hline & 5 & 4 & 3 & 2 & 1 \\
\hline \multicolumn{6}{|l|}{ Economic } \\
\hline \multicolumn{6}{|l|}{ Price of product } \\
\hline \multicolumn{6}{|l|}{ Profit on product } \\
\hline \multicolumn{6}{|l|}{ Production/logistics cost } \\
\hline \multicolumn{6}{|l|}{ Quality of product/service } \\
\hline Quality management system & & & & & \\
\hline
\end{tabular}

significant criteria. An excerpt of the first-round questionnaire is shown in Table 11. A total of 14 experts were asked to complete the questionnaire. A summary of the first-round results were given to the panelists for reference, and then the panelists were asked to fill out the second-round questionnaire. To achieve stable results, we conducted a third round. Finally, the mean score of each criterion was computed as the final score, and the first 12 criteria were selected as the criteria system, as shown in Table 12.

After the opinions of the industry experts and academics were analyzed, we created 12 PL-SSS criteria using existing research and the practical requirements of the retail field. Three exclusive criteria are proposed: green packages and labels; relationships to manufacturing brands; and product traceability. According to the feedback from panelists, green packages and labels require using green materials and also designing green styles and expressing green hope, because private-label products are sold directly to consumers. Additionally, specialists think that product traceability indicates reliability to consumers, particularly in food categories, such as eggs and milk. As technology progresses, it is becoming economically feasible for suppliers to include traceable devices in their products. Additionally, a close relationship to a national brand may imply that a product is of a high quality. Therefore, the developed criteria system is sustainable and practical. For all these reasons, these criteria are appropriate for regional retailers that lack manufacturing expertise.

\section{Weight computing}

The chief executive officer $\left(D_{1}\right)$, purchasing manager $\left(D_{2}\right)$, and marketing manager $\left(D_{3}\right)$ form the committee as a decision group. After preliminary screening, five manufacturers $\left(A_{1}, A_{2}, A_{3}, A_{4}, A_{5}\right)$ remained in the candidate list for further evaluation. The decision-making process shows the PL-SSS application of the weight measurement method 
Table 12 Private-label SSS criteria

\begin{tabular}{|c|c|c|c|}
\hline Sustainability dimensions & No & Criteria & Specification \\
\hline \multirow[t]{5}{*}{ Economic } & 1 & Affordable price (AP) & The lowest market price that supplier can offer to the purchaser \\
\hline & 2 & Quality-related certificate (QRC) & $\begin{array}{l}\text { Whether the suppliers have quality-related certificates, such as } \\
\text { ISO9000 and QS9000, etc }\end{array}$ \\
\hline & 3 & Lead time required (LDE) & $\begin{array}{l}\text { Lead time ensures that products are supplied within a marginal } \\
\text { lead time }\end{array}$ \\
\hline & 4 & Order flexibility (OF) & Suppliers are flexible to adapt the order quantity of retailers \\
\hline & 5 & Design capacity (DC) & The capability of launching new products \\
\hline \multirow[t]{4}{*}{ Environmental } & 6 & Green package and label (GPL) & $\begin{array}{l}\text { The capability of suppliers to consider environmental issues with } \\
\text { regard to packaging and labelling material and design }\end{array}$ \\
\hline & 7 & Environment-related certificates (ERC) & $\begin{array}{l}\text { Whether the supplier has environment-related certificates, such as } \\
\text { ISO } 14,000\end{array}$ \\
\hline & 8 & Green design and purchase (GDP) & $\begin{array}{l}\text { Incorporate eco-friendly practices at the design and purchasing } \\
\text { stages }\end{array}$ \\
\hline & 9 & Green manufacturing (GM) & $\begin{array}{l}\text { The production processes use fewer natural resources, reduce } \\
\text { waste and pollution, reuse materials, recycle, and moderate } \\
\text { emission }\end{array}$ \\
\hline \multirow[t]{3}{*}{ Social } & 10 & Relationship to manufacturing brand (RMB) & $\begin{array}{l}\text { Whether suppliers have a long-term relationship with the manu- } \\
\text { facturing brand }\end{array}$ \\
\hline & 11 & Information disclosure (IS) & $\begin{array}{l}\text { Whether the supplier provides information to their customers and } \\
\text { stakeholders with regard to material used, carbon emissions and } \\
\text { toxins released during production, etc }\end{array}$ \\
\hline & 12 & Product traceability & Whether products can be traced to the place of origin \\
\hline
\end{tabular}

(Algorithm 2) and fuzzy VIKOR (Algorithm 3) compared to the 12 selected criteria (Table 12).

First, three decision-makers are asked to complete the criteria and supplier evaluation. The results are shown in Tables 13 and 14. Their linguistic variables are transferred to TFNs to construct a fuzzy criteria evaluation matrix and fuzzy decision matrix. The data pre-processing algorithm is used to aggregate and defuzzy the subjective weight matrix and decision matrix (Table 15). Then, its results are input to Algorithm 2 to compute the comprehensive weight. The results of $E n_{j}, D G_{j}, w_{j}^{o}$ values are shown in Table 16.

The subjective weights, objective weights, and overall weights are shown in Table 17. Many factors in subjective weights exhibit equal importance, particularly in economic indexes. It is difficult to distinguish the importance of criteria using only subjective weights; therefore, the given entropy weight compensates for the weight coefficient that describes the criteria degree of differentiation. The subjective weight-replenishing objective weight is a reasonable and feasible weight measurement system. Also, although decision-makers tend to prefer to use affordable pricing as a criterion, the overall weight of affordable pricing is relatively low. Experts indicated that this result may be caused by the following reason: price is deemed the baseline for supplier evaluation; thus, only alternatives that meet the basic price requirement will be evaluated in more detail in other effects.
Regarding comprehensive weights, order flexibility; green packages and labels; relationships to manufacturing brands; and order traceability are important in PL-SSSs. These criteria are important to decision-makers' perspectives and exhibit a high degree of differentiation. Compared to the traditional manufacturing industry, PL-SSSs are more customer-oriented, allowing retailers to express their green image to customers. Also, the demand for privatelabel products is relatively low, which may require suppliers

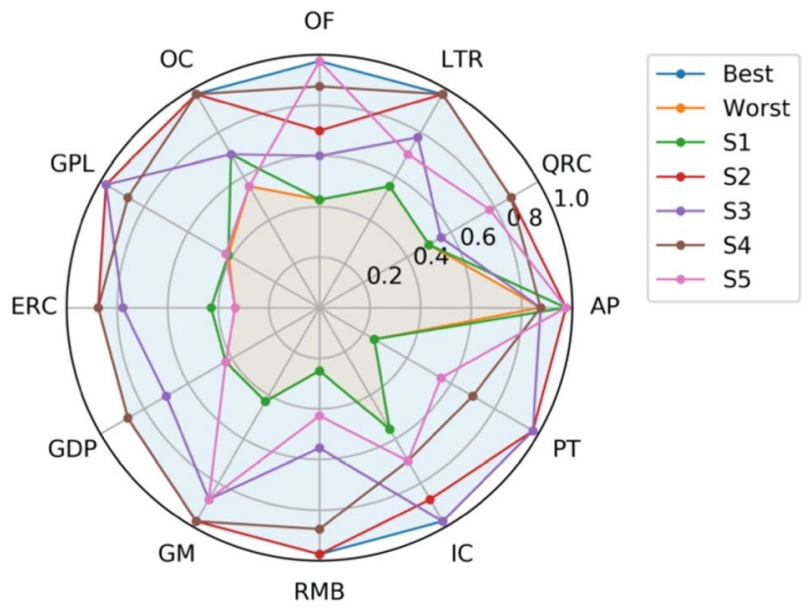

Fig. 7 Supplier performance based on each criterion 
to be flexible in how they produce low product quantities. Also, the production standardization of consumer goods is relatively lower than that of industrial products; therefore, the significance of criteria is embodied in the value added to products, such as traceability and green packages.

\section{Supplier evaluation}

To evaluate suppliers, the comprehensive weight matrix and decision matrix are used as the input to evaluate candidate performance via the VIKOR method (Algorithm 4). Table 18 shows the best $\left(r^{*}\right)$ and worst $\left(r^{-}\right)$sub-criteria performance, and the final outputs of $S, R, Q$ values are shown in Table 19. We also show the results produced by the TOPSIS (technique for order preference by similarity to ideal solution) method, which indicate that the best alternative has the longest distance to the negative ideal solution and the shortest distance to the positive ideal solution [30].

Although $A_{2}$ is ranked best in the $S, R, Q$ values, it has no acceptable advantage: $Q\left(A_{4}\right)-Q\left(A_{2}\right) \nsupseteq D Q$ $(0.0765-0 \nsupseteq 0.25)$. Therefore, $A_{2}, A_{4}$ are considered to be a set of compromise solutions by the VIKOR method. The TOPSIS method shows that $A_{2}$ is ranked best and should be chosen as the best supplier. Compared to the TOPSIS method, the VIKOR method provides a solution with acceptable advantages along with the best solution. According to Fig. 7, $A_{4}$ exhibits outstanding performance compared to the other three candidates. A more important fact in practical PL-SSS is that retailers tend to choose more than one foundry to guarantee supply stability and safety stock. Different from the motor and electronic industry, the retail industry, which is part of the consumption sector, has different requirements for suppliers, which focuses on product diversity rather than absolute standardization. Therefore, the VIKOR method's compromise solutions are more applicable when solving PL-SSS issues.

We investigated the selected suppliers and found that $A_{2}$ is a large national brand manufacturer, and $A_{4}$ is a stateowned enterprise. The results of this study also show that these two types of suppliers have strong competitive edges in environmental and social performance. Regional retailers also tend to choose manufacturers with endorsements of large national brands or government backgrounds according to feedback from decision-makers, perhaps because regional retailers lack manufacturing expertise and practices to regulate production.

\section{Conclusions}

Although private labels have long-term credibility and have been developed extensively in Europe and North America, they can be characterized as start-ups among Chinese regional retailers. With today's fierce competitive environment in the retail industry, regional retailers must innovate boldly and differentiate their private-label products to reinforce their competitiveness. However, regional retailers, as downstream enterprises of the supply chain, lack production experience. Therefore, the selection of private-label product manufacturers has become an important factor. To our knowledge, a few studies have evaluated retail privatelabel suppliers. This paper proposes a three-phase integrated MCDM approach called the PL-SSS model, which that combines the Delphi method with fuzzy entropy-VIKOR, to select sustainable suppliers for private-label product manufacturing. We complete four aspects of the study: (1) establish PL-SSS criteria system with 12 criteria; (2) propose a comprehensive weight algorithm with subjective and objective weights; (3) extend the VIKOR method to evaluate suppliers; and (4) compare and analyze the rank results of the VIKOR and TOPSIS methods. Finally, we use a case study to demonstrate the PL-SSS model, which is shown to be an easy and flexible method that can identify reliable and consistent solutions, particularly in customer-oriented and mass-customized private-label businesses. Based on the results of this study, foundry experience and green product packages are worthwhile criteria for retailers in PL-SSSs. The last two phases of the PL-SSS model could be used to evaluate private-label suppliers in practice.

The PL-SSS model can improve the sustainability of private-label manufacturers and make retailers stand out in competitive markets. Other industries could also use this supplier selection model as a reference and tailor the criteria according to their particular business situation. Procurement strategies derived from the results of this study with proper performance will foster better and smoother relationships between private-label manufacturers and retailers. Incorporating sustainability into each part of the retail supply chain will promote the sustainable development of societies, and future studies should develop investigate case studies in different retail settings to complement and refine the criteria described in this study. Additionally, other MCDM techniques, such as TOPSIS and PROMETHEE, could also be used to solve this problem in comparative studies.

\section{Appendix}

See Tables 13, 14, 15, 16, 17, 18 and 19. 
Table 13 Importance weight of each criterion

Table 14 Rates of alternatives

Table 15 Defuzzy subjective weights and fuzzy decision rates

\begin{tabular}{lllllllllllll}
\hline & C1 & C2 & C3 & C4 & C5 & C6 & C7 & C8 & C9 & C10 & C11 & C12 \\
\hline & AP & QRC & LTR & OF & DC & GPL & ERC & GDP & GM & RMB & IC & PT \\
D1 & VH & VH & M & H & H & VH & M & H & M & VH & M & H \\
D2 & VH & H & H & VH & H & VH & M & M & M & H & L & H \\
D3 & H & VH & H & VH & VH & H & H & H & H & H & L & VH \\
\hline
\end{tabular}

\begin{tabular}{|c|c|c|c|c|c|c|c|c|c|c|c|c|c|}
\hline & & $\mathrm{C} 1$ & $\mathrm{C} 2$ & C3 & $\mathrm{C} 4$ & C5 & C6 & C7 & C8 & C9 & C10 & C11 & $\mathrm{C} 12$ \\
\hline \multirow[t]{5}{*}{ D1 } & A1 & VG & $\mathrm{F}$ & $\mathrm{F}$ & MP & $\mathrm{F}$ & MG & MP & MP & MP & $\mathrm{P}$ & F & $\mathrm{P}$ \\
\hline & A2 & VG & $\mathrm{G}$ & VG & MG & VG & VG & $\mathrm{G}$ & $\mathrm{G}$ & VG & VG & G & VG \\
\hline & A3 & G & F & MG & MP & MG & VG & MG & MG & G & $\mathrm{F}$ & VG & VG \\
\hline & A4 & G & $\mathrm{G}$ & VG & G & VG & $\mathrm{G}$ & G & $\mathrm{G}$ & VG & G & MG & MG \\
\hline & A5 & VG & MG & MG & VG & $\mathrm{F}$ & MP & $\mathrm{F}$ & MP & G & MP & MG & $\mathrm{F}$ \\
\hline \multirow[t]{5}{*}{ D2 } & A1 & VG & F & $\mathrm{F}$ & F & G & $\mathrm{P}$ & $\mathrm{F}$ & MP & $\mathrm{F}$ & $\mathrm{P}$ & F & $\mathrm{P}$ \\
\hline & A2 & $\mathrm{G}$ & VG & $\mathrm{G}$ & $\mathrm{MG}$ & $\mathrm{G}$ & VG & $\mathrm{G}$ & $\mathrm{G}$ & VG & VG & VG & VG \\
\hline & A3 & $\mathrm{G}$ & F & $\mathrm{F}$ & $\mathrm{P}$ & $\mathrm{G}$ & G & F & $\mathrm{G}$ & VG & $\mathrm{F}$ & VG & $\mathrm{G}$ \\
\hline & A4 & VG & G & $\mathrm{G}$ & MG & $\mathrm{G}$ & G & $\mathrm{G}$ & VG & $\mathrm{G}$ & MG & G & G \\
\hline & A5 & VG & $\mathrm{F}$ & G & $\mathrm{G}$ & $\mathrm{MG}$ & $\mathrm{F}$ & MG & $\mathrm{F}$ & F & MP & G & MG \\
\hline \multirow[t]{5}{*}{ D3 } & A1 & VG & G & MG & MP & $\mathrm{G}$ & VP & F & $\mathrm{F}$ & F & MP & MP & MP \\
\hline & A 2 & $\mathrm{G}$ & VG & VG & $\mathrm{G}$ & VG & G & VG & $\mathrm{G}$ & VG & VG & VG & $\mathrm{G}$ \\
\hline & A3 & $\mathrm{G}$ & MG & $\mathrm{F}$ & MP & $\mathrm{G}$ & $\mathrm{G}$ & F & $\mathrm{G}$ & $\mathrm{G}$ & $\mathrm{MG}$ & VG & G \\
\hline & A4 & VG & VG & $\mathrm{G}$ & MG & $\mathrm{G}$ & G & $\mathrm{G}$ & $\mathrm{G}$ & $\mathrm{G}$ & $\mathrm{G}$ & G & G \\
\hline & A5 & VG & MG & G & G & MG & MP & MG & $\mathrm{F}$ & MG & $\mathrm{F}$ & G & $\mathrm{F}$ \\
\hline
\end{tabular}

\begin{tabular}{|c|c|c|c|c|c|c|c|c|c|c|c|c|c|}
\hline \multirow{2}{*}{$w_{j}^{s}$} & & $\mathrm{C} 1$ & $\mathrm{C} 2$ & C3 & $\mathrm{C} 4$ & C5 & C6 & C7 & C8 & C9 & $\mathrm{C} 10$ & C11 & $\mathrm{C} 12$ \\
\hline & & 0.83 & 0.83 & 0.72 & 0.83 & 0.82 & 0.83 & 0.68 & 0.72 & 0.68 & 0.82 & 0.48 & 0.82 \\
\hline \multirow[t]{5}{*}{$r_{i j}$} & A1 & 0.98 & 0.64 & 0.58 & 0.38 & 0.79 & 0.11 & 0.42 & 0.38 & 0.42 & 0.21 & 0.58 & 0.21 \\
\hline & A2 & 0.89 & 0.91 & 0.91 & 0.76 & 0.91 & 0.91 & 0.89 & 0.88 & 0.98 & 0.98 & 0.91 & 0.91 \\
\hline & A3 & 0.88 & 0.58 & 0.58 & 0.24 & 0.79 & 0.89 & 0.58 & 0.79 & 0.89 & 0.58 & 0.98 & 0.89 \\
\hline & A4 & 0.91 & 0.89 & 0.89 & 0.76 & 0.89 & 0.88 & 0.88 & 0.89 & 0.89 & 0.79 & 0.79 & 0.79 \\
\hline & A5 & 0.98 & 0.62 & 0.79 & 0.89 & 0.62 & 0.38 & 0.53 & 0.42 & 0.68 & 0.38 & 0.79 & 0.58 \\
\hline
\end{tabular}

Table 16 Entropy measure, divergence, and objective weights

\begin{tabular}{|c|c|c|c|c|c|c|c|c|c|c|c|c|}
\hline & $\mathrm{C} 1$ & $\mathrm{C} 2$ & C3 & $\mathrm{C} 4$ & C5 & C6 & $\mathrm{C} 7$ & $\mathrm{C} 8$ & C9 & $\mathrm{C} 10$ & C11 & $\mathrm{C} 12$ \\
\hline $\mathrm{En}_{j}$ & 0.9994 & 0.9885 & 0.9885 & 0.9419 & 0.9946 & 0.8957 & 0.9741 & 0.963 & 0.9763 & 0.9278 & 0.9912 & 0.9439 \\
\hline $\mathrm{DG}_{j}$ & 0.0006 & 0.0115 & 0.0115 & 0.0581 & 0.0054 & 0.1043 & 0.0259 & 0.037 & 0.0237 & 0.0722 & 0.0088 & 0.0561 \\
\hline$w_{j}^{0}$ & 0.0015 & 0.0278 & 0.0277 & 0.1398 & 0.0131 & 0.2512 & 0.0624 & 0.0892 & 0.0571 & 0.174 & 0.0211 & 0.1352 \\
\hline
\end{tabular}


Table 17 PL-SSS criteria weights

Table $18 r^{*}$ and $r^{-}$for each criterion

\begin{tabular}{|c|c|c|c|c|c|c|c|}
\hline \multirow{2}{*}{$\begin{array}{l}\text { No. } 1 \\
\text { C1 }\end{array}$} & \multirow{2}{*}{$\begin{array}{l}\text { Criteria } \\
\mathrm{AP}\end{array}$} & \multicolumn{2}{|c|}{ Subjective weight } & \multicolumn{2}{|c|}{ Objective weight } & \multicolumn{2}{|c|}{$\begin{array}{l}\text { Comprehensive } \\
\text { weight }\end{array}$} \\
\hline & & 0.0919 & $1 \mathrm{st}$ & 0.0015 & 12 th & 0.0133 & 12 th \\
\hline $\mathrm{C} 2$ & QRC & 0.0919 & $1 \mathrm{st}$ & 0.0278 & 8th & 0.0564 & 8th \\
\hline $\mathrm{C} 3$ & LTR & 0.0790 & 8 th & 0.0277 & 9th & 0.0522 & 9th \\
\hline $\mathrm{C} 4$ & $\mathrm{OF}$ & 0.0919 & $1 \mathrm{st}$ & 0.1398 & 3rd & 0.1265 & 3rd \\
\hline C5 & DC & 0.0901 & 5 th & 0.0131 & 11 th & 0.0383 & 10th \\
\hline C6 & GPL & 0.0919 & $1 \mathrm{st}$ & 0.2512 & $1 \mathrm{st}$ & 0.1696 & $1 \mathrm{st}$ \\
\hline C7 & ERC & 0.0754 & 10th & 0.0624 & 6th & 0.0765 & 6th \\
\hline C8 & GDP & 0.0790 & 8th & 0.0892 & 5 th & 0.0937 & 5 th \\
\hline C9 & GM & 0.0754 & 10th & 0.0571 & 7th & 0.0732 & 7th \\
\hline $\mathrm{C} 10$ & RMB & 0.0901 & 5 th & 0.1740 & 2nd & 0.1397 & 2nd \\
\hline $\mathrm{C} 11$ & IC & 0.0533 & 12 th & 0.0211 & 10th & 0.0374 & 11th \\
\hline $\mathrm{C} 12$ & PT & 0.0901 & 5 th & 0.1352 & 4th & 0.1231 & 4 th \\
\hline
\end{tabular}

Table 19 VIKOR and TOPSIS results

\begin{tabular}{lllllllllllll}
\hline & $\mathrm{C} 1$ & $\mathrm{C} 2$ & $\mathrm{C} 3$ & $\mathrm{C} 4$ & $\mathrm{C} 5$ & $\mathrm{C} 6$ & $\mathrm{C} 7$ & $\mathrm{C} 8$ & $\mathrm{C} 9$ & $\mathrm{C} 10$ & $\mathrm{C} 11$ & $\mathrm{C} 12$ \\
\hline$r^{*}$ & 0.975 & 0.908 & 0.9083 & 0.8917 & 0.9083 & 0.9083 & 0.8917 & 0.8917 & 0.975 & 0.975 & 0.975 & 0.9083 \\
$r^{-}$ & 0.875 & 0.5833 & 0.5833 & 0.2417 & 0.6167 & 0.1083 & 0.4167 & 0.3833 & 0.4167 & 0.2083 & 0.5833 & 0.2083 \\
\hline
\end{tabular}

\begin{tabular}{|c|c|c|c|c|c|c|c|c|}
\hline \multicolumn{7}{|c|}{ VIKOR results } & \multirow{2}{*}{\multicolumn{2}{|c|}{$\begin{array}{l}\text { TOPSIS results } \\
\text { Closeness coef- } \\
\text { ficient }\end{array}$}} \\
\hline & $S_{i}$ & & $R_{i}$ & & $Q_{i}$ & & & \\
\hline A1 & 0.926 & 5 th & 0.1696 & 5 th & 1 & 5 th & 0.1154 & 4th \\
\hline A2 & 0.0465 & $1 \mathrm{st}$ & 0.0259 & $1 \mathrm{st}$ & 0 & $1 \mathrm{st}$ & 6.2322 & $1 \mathrm{st}$ \\
\hline A3 & 0.4206 & $3 r d$ & 0.1265 & $3 \mathrm{rd}$ & 0.5627 & $3 \mathrm{rd}$ & 2.2338 & $3 \mathrm{rd}$ \\
\hline A4 & 0.1347 & 2nd & 0.0334 & 2nd & 0.0761 & 2nd & 4.1934 & 2nd \\
\hline A5 & 0.5861 & 4th & 0.1113 & 4th & 0.6038 & 4th & 0.9098 & 5th \\
\hline
\end{tabular}

Acknowledgements This work was supported by Chinese National Funding of Social Science under grant 20BGL001.

\section{Declarations}

Conflict of interest The authors declare no conflict of interest. We ensure the availability of data and material and code.

Open Access This article is licensed under a Creative Commons Attribution 4.0 International License, which permits use, sharing, adaptation, distribution and reproduction in any medium or format, as long as you give appropriate credit to the original author(s) and the source, provide a link to the Creative Commons licence, and indicate if changes were made. The images or other third party material in this article are included in the article's Creative Commons licence, unless indicated otherwise in a credit line to the material. If material is not included in the article's Creative Commons licence and your intended use is not permitted by statutory regulation or exceeds the permitted use, you will need to obtain permission directly from the copyright holder. To view a copy of this licence, visit http://creativecommons.org/licenses/by/4.0/.

\section{References}

1. Aissaoui N, Haouari M, Hassini E (2007) Supplier selection and order lot sizing modeling: a review. Comput Oper Res 34:3516-3540

2. Akman G, Pışkın H (2013) Evaluating green performance of suppliers via analytic network process and TOPSIS. J Ind Eng 2013

3. Azadnia AH, Saman MZM, Wong KY (2014) Sustainable supplier selection and order lot-sizing: an integrated multi-objective decision-making process. Int J Prod Res 53:383-408. https://doi. org/10.1080/00207543.2014.935827

4. Azimifard A, Moosavirad SH, Ariafar S (2018) Selecting sustainable supplier countries for Iran's steel industry at three levels by using AHP and TOPSIS methods. Resour Policy 57:30-44

5. Bai C, Kusi-Sarpong S, Badri Ahmadi H, Sarkis J (2019) Social sustainable supplier evaluation and selection: a group decisionsupport approach. Int J Prod Res 57:7046-7067. https://doi.org/ 10.1080/00207543.2019.1574042

6. Bai C, Sarkis J (2010) Integrating sustainability into supplier selection with grey system and rough set methodologies. Int $\mathrm{J}$ Prod Econ 124:252-264 
7. Banaeian N, Mobli H, Nielsen IE, Omid M (2015) Criteria definition and approaches in green supplier selection - a case study for raw material and packaging of food industry. Prod Manuf Res 3:149-168

8. Baskaran V, Nachiappan S, Rahman S (2012) Indian textile suppliers' sustainability evaluation using the grey approach. Int J Prod Econ 135:647-658

9. Bellman RE, Zadeh LA (1970) Decision-making in a fuzzy environment. Manag Sci 17:B-141-B-164

10. Bender PS, Brown RW, Isaac MH, Shapiro JF (1985) Improving purchasing productivity at IBM with a normative decision support system. Interfaces 15:106-115

11. Bockholdt K, Kemper J, Brettel M (2020) Private label shoppers between fast fashion trends and status symbolism - a customer characteristics investigation. J Retail Consum Serv 52:101883

12. Brown BB (1968) Delphi process: a methodology used for the elicitation of opinions of experts. Rand Corp Santa Monica CA

13. Burton TT (1988) JIT/repetitive sourcing strategies: 'Tying The Knot'With Y. Prod Invent Manag J 29:38

14. Büyüközkan G, Çifçi G (2011) A novel fuzzy multi-criteria decision framework for sustainable supplier selection with incomplete information. Comput Ind 62:164-174

15. Büyüközkan G, Cifçi G (2012) A novel hybrid MCDM approach based on fuzzy DEMATEL, fuzzy ANP and fuzzy TOPSIS to evaluate green suppliers. Expert Syst Appl 39:3000-3011

16. Cassen R (1987) Our common future: report of the world commission on environment and development. JSTOR

17. Choi SC, Coughlan AT (2006) Private label positioning: quality versus feature differentiation from the national brand. J Retail 82:79-93

18. Dalkey N, Helmer O (1963) An experimental application of the Delphi method to the use of experts. Manage Sci 9:458-467

19. De Boer L, Labro E, Morlacchi P (2001) A review of methods supporting supplier selection. Eur J Purch Supply Manag 7:75-89

20. De Jong K (2015) Managing private labels: sharing knowledge from research and practice. International Private Label Consult (IPLC)

21. Dickson GW (1966) An analysis of vendor selection systems and decisions. J Purch 2:5-17

22. Dou Y, Zhu Q, Sarkis J (2014) Evaluating green supplier development programs with a grey-analytical network process-based methodology. Eur J Oper Res 233:420-431

23. Elkington J (1998) Partnerships from cannibals with forks: the triple bottom line of 21st-century business. Environ Qual Manage 8:37-51

24. Fitzell PB (1992) Private label marketing in the 1990s: the evolution of price labels into global brands. Exclusive Brands Llc

25. Glenn JC, Gordon TJ (2009) The Millennium project: futures research methodology, version

26. Golan A, Judge G, Miller D (1997) Maximum entropy econometrics: robust estimation with limited data

27. Govindan K, Khodaverdi R, Jafarian A (2013) A fuzzy multi criteria approach for measuring sustainability performance of a supplier based on triple bottom line approach. J Clean Prod 47:345-354

28. Hashemi SH, Karimi A, Tavana M (2015) An integrated green supplier selection approach with analytic network process and improved Grey relational analysis. Int J Prod Econ 159:178-191

29. Hoch SJ, Banerji S (1993) When do private labels succeed? MIT Sloan Manag Rev 34:57

30. Hwang C-L, Yoon K (1981) Methods for multiple attribute decision making. Multiple attribute decision making. Springer, New York, pp 58-191

31. Igarashi M, de Boer L, Fet AM (2013) What is required for greener supplier selection? A literature review and conceptual model development. J Purch Supply Manag 19:247-263
32. Kannan D, de Sousa Jabbour ABL, Jabbour CJC (2014) Selecting green suppliers based on GSCM practices: using fuzzy TOPSIS applied to a Brazilian electronics company. Eur J Oper Res 233:432-447

33. Lee AH, Kang H-Y, Hsu C-F, Hung H-C (2009) A green supplier selection model for high-tech industry. Expert Syst Appl 36:7917-7927

34. Luthra S, Govindan K, Kannan D, Mangla SK, Garg CP (2017) An integrated framework for sustainable supplier selection and evaluation in supply chains. J Clean Prod 140:1686-1698

35. Manoochehri GH (1984) Suppliers and the just-in-time concept. J Purch Mater Manag 20:16-21

36. Newman RG (1988) Insuring quality: purchasing's role. J Purch Mater Manag 24:14-21

37. Nielson (2014) The state of private label around the world: where it's growing, where It's Not, and what the future holds. New York

38. Olson EL (2012) Supplier inferences to enhance private label perceptions. J Bus Res 65:100-105

39. Opricovic S (1998) Multicriteria optimization of civil engineering systems. Fac Civil Eng Belgrade 2:5-21

40. PLMA (2016) PLMA's 2016 private label yearbook: a statistical guide to today's store brands. New York

41. PLMA (2020) Market profile. https://plma.com/storeBrands/sbt13. html. Accessed 14 Sep 2020

42. Qin J, Liu X, Pedrycz W (2017) An extended TODIM multicriteria group decision making method for green supplier selection in interval type-2 fuzzy environment. Eur J Oper Res 258:626-638

43. Rosenfeld R (1996) A maximum entropy approach to adaptive statistical language modeling.

44. Ruiz-Real JL, Uribe-Toril J, Gázquez-Abad JC, de Pablo VJ (2019) Sustainability and retail: analysis of global research. Sustainability $11: 14$

45. Saaty TL (2008) Decision making with the analytic hierarchy process. Int J Serv Sci 1:83-98

46. Sackman H (1974) Delphi assessment: expert opinion, forecasting, and group process. Rand Corp, Santa Monica

47. Sarkis J, Dhavale DG (2015) Supplier selection for sustainable operations: a triple-bottom-line approach using a Bayesian framework. Int J Prod Econ 166:177-191

48. Shannon CE (2001) A mathematical theory of communication. ACM SIGMOBILE Mobile Comput Commun Rev 5:3-55

49. Shen L, Olfat L, Govindan K, Khodaverdi R, Diabat A (2013) A fuzzy multi criteria approach for evaluating green supplier's performance in green supply chain with linguistic preferences. Resour Conserv Recycl 74:170-179

50. Ulrych TJ, Bishop TN (1975) Maximum entropy spectral analysis and autoregressive decomposition. Rev Geophys 13:183-200

51. Wang T-C, Lee H-D (2009) Developing a fuzzy TOPSIS approach based on subjective weights and objective weights. Expert Syst Appl 36:8980-8985

52. Wang X, Chen Y, Yang N, Deng W, Wang Q, Li N, Yao L, Wei D, Chen G, Yang K (2015) Methodology and reporting quality of reporting guidelines: systematic review. BMC Med Res Methodol $15: 1-9$

53. Weber CA, Current JR, Benton W (1991) Vendor selection criteria and methods. Eur J Oper Res 50:2-18

54. Wiese A, Zielke S, Toporowski W (2015) Sustainability in retailing-research streams and emerging trends. Int J Retail Distrib Manag

55. Yu P-L (1973) A class of solutions for group decision problems Manage Sci 19:936-946

56. Zadeh LA (1965) Fuzzy sets. Inf Control 8:338-353

57. Zhang M, Tse YK, Doherty B, Li S, Akhtar P (2018) Sustainable supply chain management: confirmation of a higher-order model. Resour Conserv Recycl 128:206-221 
58. Zimmer K, Fröhling M, Schultmann F (2016) Sustainable supplier management-a review of models supporting sustainable supplier selection, monitoring and development. Int J Prod Res 54:1412-1442
Publisher's Note Springer Nature remains neutral with regard to jurisdictional claims in published maps and institutional affiliations. 